\section{庭球における打球方向の失敋要因とその籍正法 について}

\section{緹田と目的}

$$
\text { 東北大兴 小山 又 次 }
$$

“そもそもテニスとは，ごく简単にいらならば「金網 の中で小さなボールを追つかけまわしながら、いかにし てネットを越して根手のコートヘボールを送ろらか」と いら努力の過程に寸ぎないのである.しかし「人生は短 く，芸術は長し」で単にそれだけのことであるテニス が、いさやつてみるともてあますはどむずかしいものな のである."……とは名ューチ，ウイン・イースの言莱 である.それはど自己゙意に反してボールはネットにひ つか」りやすく，またコートの外にとび出したがるので ある、それは明らかにストロークのむずかしさを証明し ているものである.

そこで私はストロークの失敗要因の把据とその智正法 について考えてみることは，ラヶットを握つてはじめて コートに立つ生徒が「早く上手になりたい」と願う心 と, それらの生徒を指刑する教師が「早く上達させた い」と思ら気持にいくらかでも役卉ち得るものと信じて 本研究を企てたわけである。

\section{用查と方法}

次のよらな方法で打球方向の失敗の実瑟を調查した。 体育館内のテニス・ボード（巾 $10 \mathrm{~m}$, 高さ $4 \mathrm{~m}$ ) に床 上 $1 \mathrm{~m}$ の高さで直径 $1 \mathrm{~m}$ の円型楼的を白ペンキで描 き，テニス・ボードから $11 \mathrm{~m} 89 \mathrm{~cm}$ はなれたベース・ラ インの後方に被験者を立たせ，さきの縲的の中心を狙つ てい打のボールをョーテイシー・ストローク (courtesy stroke）で1 分閪以内に打たせる.但し取初のボール2 䇢は練習用とし，10筒のボールの成績（成功点, 失敗 点、失敗方向型) を記録する.

〔街〕コーテイシー・ストロークとはハーフ・スイン グのフオフー・ハンド・ボレーで自分でトスしたボール をノ一・ハンドで打つ打球法のことである。

被鏂者は次のとおりである。

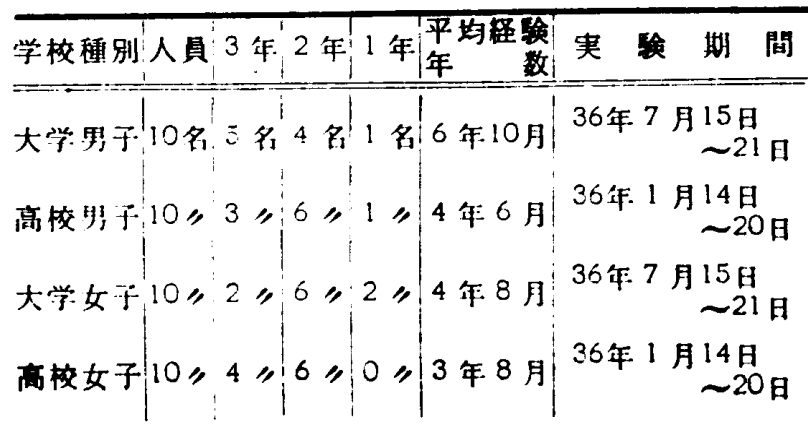

\section{结果と宩家}

打球方向の失敗の実態は次のとおりである.

\begin{tabular}{|c|c|c|c|c|c|c|c|}
\hline 学校種別 & 人員 & 右上型 & 左上垔 & 右下琹 & 左下玨 & 成功 & 失 敗 \\
\hline 学 & 10名 & 3 名 & 5 名 & 0 名 & 2 名 & $78 \%$ & $22 \%$ \\
\hline ; 男子 & $10 "$ & $4 "$ & $4 "$ & $1 "$ & $1 "$ & $73 "$ & $27 "$ \\
\hline 学女子 & $10 "$ & $4 "$ & $3 "$ & $2 "$ & $1 "$ & $65 "$ & $35 "$ \\
\hline 校女子 & $10 "$ & $5 "$ & $3 "$ & $2 "$ & $0 "$ & $51 "$ & $49 "$ \\
\hline 合 部 & $40 "$ & 16 & $15 "$ & 5 & $4 "$ & & 33 \\
\hline
\end{tabular}

以上の結果から，相当年数の趽积を有する大学，高校 の遗手級のものです，いざ的を祖つてボールを打たせ てみると，高すきたり低すきたり，右にそれたり左にそ れたりして、なかなか自己の意のまっにならねというこ とが確爝できる。

そこでこのような打球方向の失敋の原因とその嵲正 法をまとめたるのが次の表である.

\begin{tabular}{|c|c|}
\hline "失政象目 & 知 \\
\hline 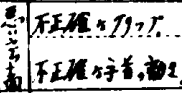 & 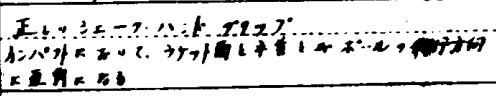 \\
\hline 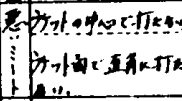 & 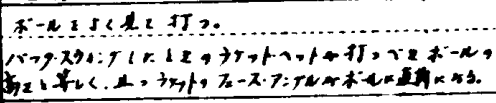 \\
\hline 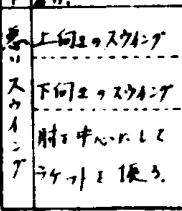 & 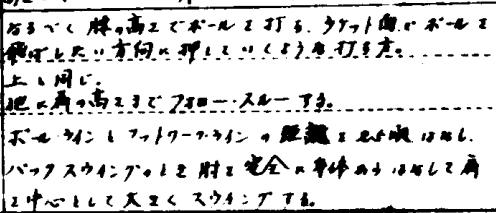 \\
\hline
\end{tabular}

\begin{tabular}{|c|c|}
\hline 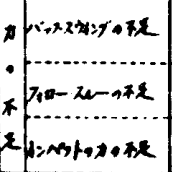 & 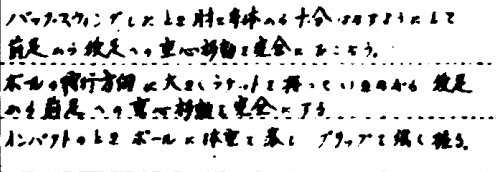 \\
\hline 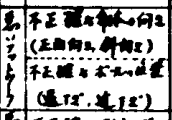 & 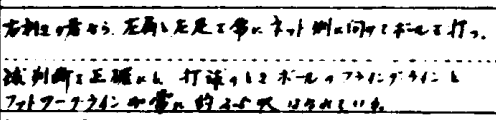 \\
\hline $\begin{array}{l}x E 2 \times 11: r \\
(+12, x+12)\end{array}$ & 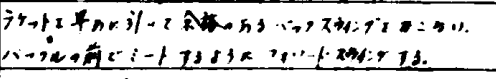 \\
\hline 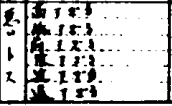 & 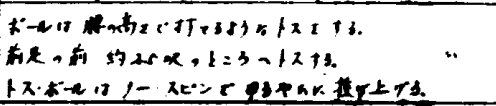 \\
\hline
\end{tabular}

もすびとして 1. 教師は常に生徒にぬ哥な基碃知識 を与え，正しい媼習ができる状䈍におくことが上達の秘 訣である。

2. 教師は生徒の久点（失敋の原因）の分析にあた り、この表から根本的な答を見出すことができょら。よ ろしく閶题の核心をとらえてそれを正しく期しなけれ ばならぬ・

3. 普通の生唗を上達させることができないのは全く 教師の指远の失攻である。

次回は旛正の果について筑告したい。 